\title{
FLAT SLAB STIFFENED WITH ONE-WAY CURVED BEAM SYSTEM
}

\author{
by GENGO MATSUI* and SHOJI SOSHIRODA** \\ Members of A.I.J.
}

\section{INTRODUCTION}

The Flat slab is generally used for the floor and roof of warehouse as well as garage. When the distance between the columns supporting the flat slab is considerably long, it is more economic to stiffen it with ribs (or beams). The Gatti wool Factory (in Rome) and the Palace of Labor (in Torino), designed by P.L. Nervi and the Taiseki Temple (in Fujinomiya), by Professor S. Aoki, are well known as the example of the slab structure reinforced by curved beams. All these slabs are reinforced by the curved beams in the principal directions in bending of isotropic flat slab. The curved beams discussed herein may be obtained by the author's method ${ }^{(1),(2)}$, which is based upon the fact that the streamlines are agree with the direction of primary beam and that the potential lines with that of secondary beam, under assumption that the primary beams alone carry the loads to these supports. Although an example of the flat slab was discussed in previous monogragh, the present paper will be reported on the one-way curved beam system in the case of the flat slab, from both theoretical and experimental view points.

\section{ANALOGY BETWEEN FLAT SLAB AND FLUID WITH OUTFLOW AND INFLOW POINTS}

The complex potential of two-dimensional stationary stream with a outflow point at the origin is expressed by

$$
f(z)=\frac{m}{2 \pi} \log z
$$

where $m$ is the quantity of the fluid streaming out from the origin. Let us assume the outflow point at the coordinates of $x=a, y=a$ and $x=-a, y=-a$, and the inflow point at those of $x=a, y=-a$ and $x=-a, y=a$, as shown in Fig. 1. The potential in this case may be obtained by applying Eq. 1 to

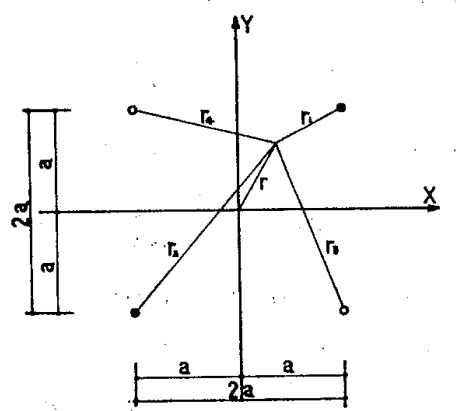

Fig. 1 Field of two-dimentional fluid with two outflow and inflow points, respectively. those points and summing these results as follows :

$$
f(z)=\frac{m}{2 \pi}\{\log (z-a-i a)+\log (z+a+i a)-\log (z-a+i a)-\log (z+a-i a)\}
$$

Let the distances from an arbitrary point to these four points be $r_{1}, r_{2}, r_{3}$ and $r_{4}$, respectively and let the angles between these lines and the $x$ axis be $\theta_{1}, \theta_{2}, \dot{\theta}_{3}$ and $\theta_{4}$, respectively. Then, Eq. 2 can be rewritten in the following from:

$$
f(z)=\frac{m}{2 \pi} \log \frac{r_{1} e^{i \theta_{1}} r_{2} e^{i \theta_{2}}}{r_{3} e^{i \theta_{3}} r_{4} e^{i \theta_{4}}}
$$

The real part of this equation is given by

$$
u=\frac{m}{2 \pi} \log \frac{r_{1} \cdot r_{2}}{r_{3} \cdot r_{4}}
$$

* Dr. Eng., Professor of Waseda University. **' Professor of Kogakuin University.

(1) G. Matsui, "Pattern of One-Way Curved Beam System and Its application", Trans. A.I.J., No. 241, March, 1976.

(2) G. Matsui, "One-Way Curved Beam System with the Regular Poligonal Plates, "Trans. of A.I.J. No. 251, January 1977. 
By transforming the above equation into the Cartesian coordinates $(x, y)$, we obtain.

$$
u=\frac{m}{4 \pi} \log \frac{\left(x^{2}+y^{2}\right)^{2}+4 a^{4}-8 a^{2} x y}{\left(x^{2}+y^{2}\right)^{2}+4 a^{4}+8 a^{2} x y}
$$

Also, using the polar coordinates $(r, \theta)$, we obtain

$$
u=\frac{m}{2 \pi} \log \frac{r^{4}+4 a^{2}\left(a^{2}-2 r^{2} \sin \theta \cos \theta\right)}{r^{4}+4 a^{2}\left(a^{2}+2 r^{2} \sin \theta \cos \theta\right)}
$$

It is assumed that the column supporting the flat slab is infinitely continuous in every direction of it. Howevr; in this case the area enclosed by the lines connecting four points will be close to that of flat slab. Let us now assume that the radius of capital in the flat slab, $R$, is very small. The shearing forces along the outer circumferential boundary in the capital are equal to aw at the intersection of colum row line with its boundary and $\sqrt{2}$ aw at the intersection of diagonal line. Under the assumption that the shearing forces between these lines change in the shape of trigonometric function, the shearing forces can be given by

$$
\left(Q_{\alpha}\right)_{R}=\left\{1+\frac{(\sqrt{2}-1)}{2}\left(1-\cos 4 \theta^{\prime}\right)\right\} a w
$$

where $\theta^{\prime}$ is the angle between the arbitrary line from the centre of capital and the column row line. The mean shearing force is equal to

$$
\frac{4}{\pi R} \int_{0}^{\pi / 4}\left\{1+\frac{(\sqrt{2}-1)}{2}\left(1-\cos 4 \theta^{\prime}\right)\right\} a w R d \theta^{\prime}=\frac{1+\sqrt{2}}{2} \text { aw }
$$

Accordingly, making use of

$$
m=\frac{1+\sqrt{2}}{2} \text { ar }
$$

as the value of $m$ in the case of fluid, Eq. (3) and Eq. (3)' represent the shearing forces in the flat slab.

Therefore, the shearing forces in the column row line of $x=a$ are obtained from Eq. (3) as follow :

$$
Q_{\alpha}=-\frac{(1+\sqrt{2})}{8 \pi} a w \log \frac{\left(a^{2}+y^{2}\right)^{2}+4 a^{2}\left(a^{2}+2 a y\right)}{\left(a^{2}+y^{2}\right)^{2}+4 a^{2}\left(a^{2}-2 a y\right)}
$$

The shearing forces in the diagonal line of $\theta=\pi / 4$ can be found from $\mathrm{Eq}$. (3) ${ }^{\prime}$ as follows :

$$
Q_{\alpha}=-\frac{(1+\sqrt{2})}{8 \pi} \text { aw } \log \frac{r^{4}+4 r^{2}\left(a^{2}+r^{2}\right)}{r^{4}+4 r^{2}\left(a^{2}-r^{2}\right)}
$$

The results for computation of $Q_{\alpha}$ are shown in Fig. 2 (a) and (b).

To verify this theory, we have performed the experiment that stretched a membrane over the square frame with side length of $30 \mathrm{~cm} \times 30 \mathrm{~cm}$ which, in the case of $a=7.5 \mathrm{~cm}$, was lifted at two outflow points and dropped at two inflow points (where the difference in height between these two points is equal to $2 \mathrm{~cm}$, respectively). Photo. 1 demonstrates the contour lines of this membrane which have been obtained from Moire method. Hence, it is seen that the shearing force $Q_{\alpha}$ is equal

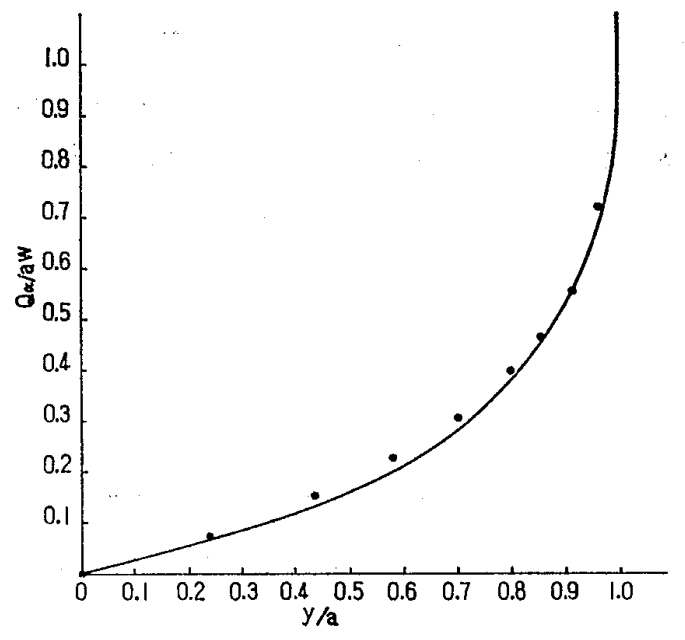

Fig. 2 (a) Shearing forces in column row line.

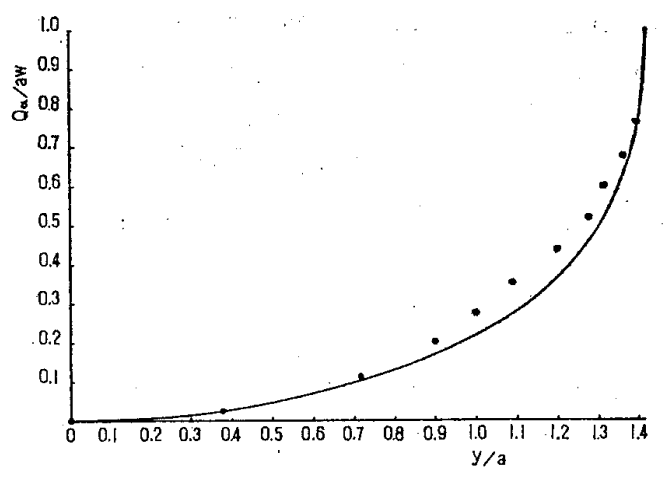

Fig. 2 (b) Shearing forces in diagonal line. 


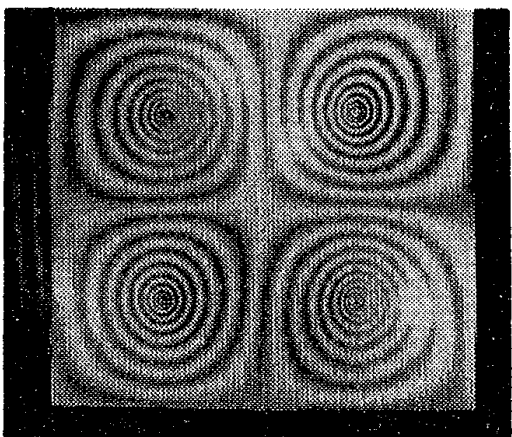

Photo. 1 Moire fringes of contour lines in the flat slab supported by small column capital.

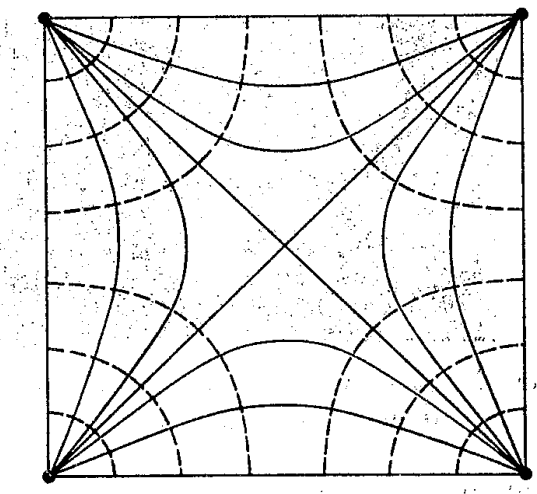

Fig. 3 The primary and secondary beams of one-way beam system in the flat slab under the assumption that the column capital is a 'point:

to zoro at the middle point of column row line. The values of shearing force which have been evaluated from this experiment are well agree with the theoretical values, as plotted by solid points in Fig. 2. The plan of the primary and secondary beams in one-way curved beam system, which have been found from the contour lines obtained, is shown in Fig. 3 , where the solid line denotes the primary boam and dashed line the secondary beam.

\section{FLAT SLAB WITH SKEW COLUMN ROW LINES}

The column row lines in flat slab are in general orthogonal. However, they are skew in the flat slab whose column rows are moved only a in the lateral direction, as shown in Fig. 4. In this case, by applying the stream line of Karman's vertex street to the potential line, we obtain the following shearing force $Q_{\alpha}$ :

$$
Q_{\alpha}=\frac{m}{2 \pi} \log \frac{\cosh \frac{\pi}{a}(y-a)-\cos \frac{\pi}{a} x}{\cosh \frac{\pi}{a}(y+a)+\cos \frac{\pi}{a} x}
$$

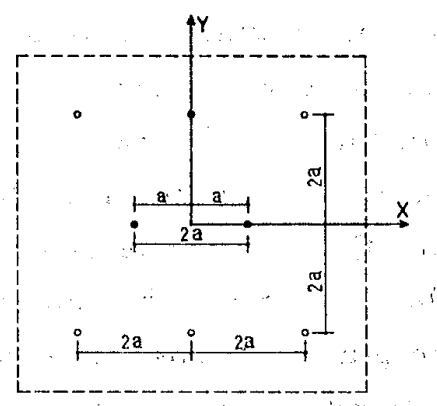

Fig. 4 Field of fluid corresponding to the flat slab with skew column row lines.

where $m \fallingdotseq(3 \times 5 / 4+2 \times \sqrt{5} / 2+1) a w / 6 \fallingdotseq 1.16$ aw. . Fig. 5 expresses the shearing forces in the $y$ avis in Fig. 4 which have been computed by Eq. (5). Analogously, the shearing forces in a skew line connecting the columns, i.e., the line connecting $t, e$ points of outflow and inflow, are represented in Fig. 6.

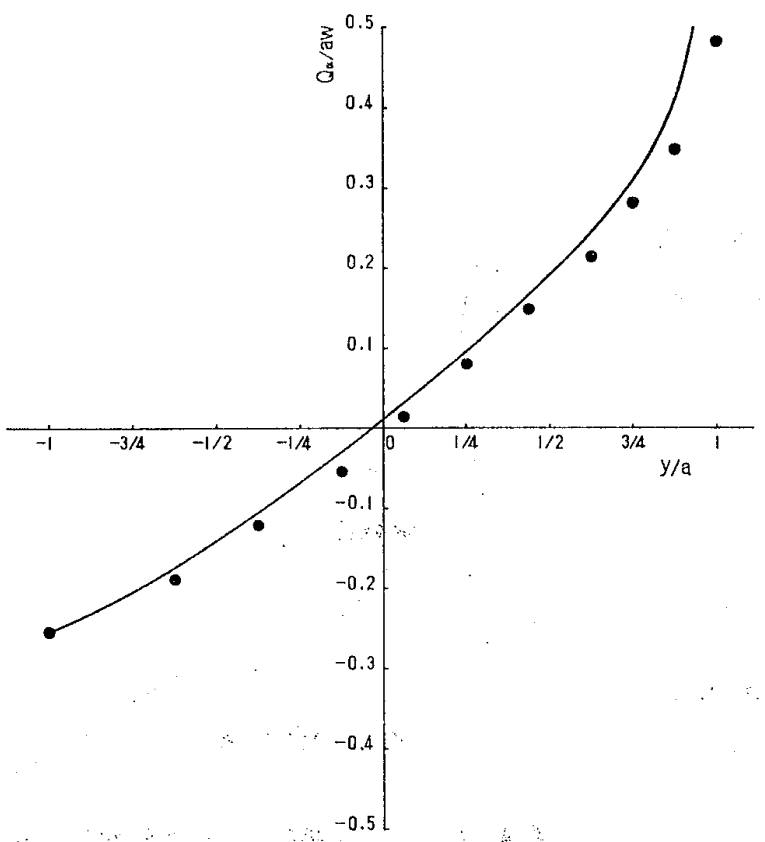

Fig. 5 Shearing forces in the $y$ axis in Fig. 4.

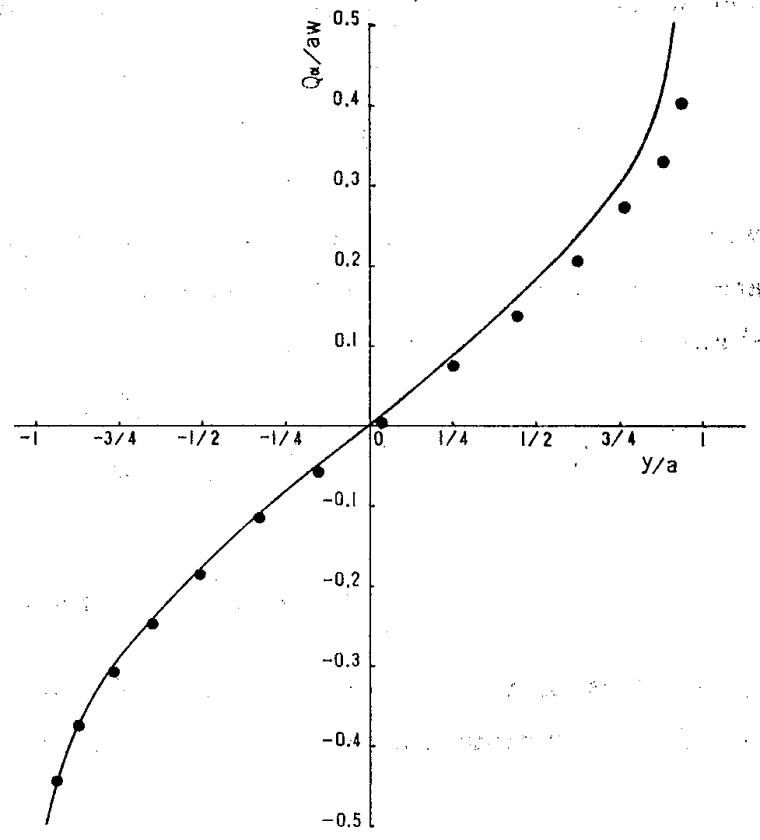

Fig. 6 Shearing forces in the line between outflow and inflow points in Fig. 4. 


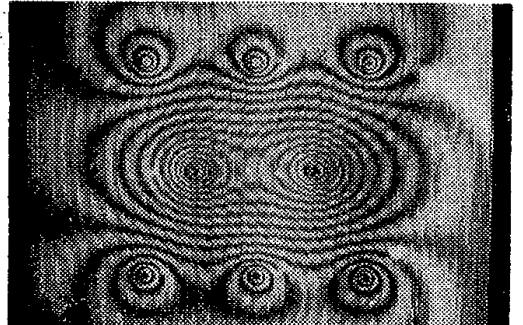

Photo, 2 Contour lines in the flat slab with skew column row lines.

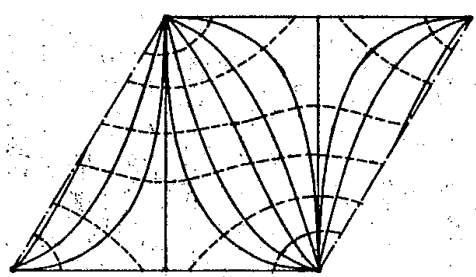

Fig. 7 The primary and secondary beams in the flat slab with skew column row lines.

Photo. 2 shows the contour lines in this case which have been obtained by Moire method. These experimental values are considerably close to the theoretical ones, as plotted by solid points in Fig. 5 and Fig. 6. However, in order that the theoretical values might been obtained for the case of two column row lines and otherwise that the experimental values for the case of three column row lines, there is a little discrepancy between both values. Fig. 7 demonstrates a plan of the primary and secondary beams, which has been evaluated by these results.

\section{SHEARING FORCES NEAR AND IN THE COLUMN CAPITAL}

In the theoretical consideration mentioned previously, the radius of the column capital was taken as a point under the assumption that it is so much small. However, it is never the point in practice. Let us hence discuss with regard to the difference between the real structure and this assumption. The contour lines near and in the column capital are so much similar to the family of concentric circle that Eq. (1) may be assumed to satisfy approximately, as seen in Photo. 1. Since the column row and diagonal lines correspond to the primary beams, the shearing forces are equal to $(a-R) w$ at the intersection between the column row line and the circumferential line of column capital and $(\sqrt{2} a-R) w$ at the intersection between the diagonal line and it. If it is assumed that the shearing forces in the area of the column capital change in the form of trigonometric func-

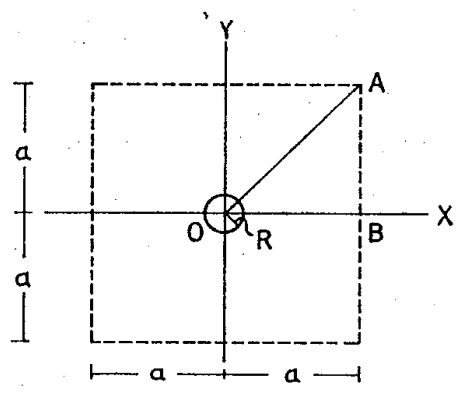

Fig. 8 Area neer and in the column capital. tion, we obtain the shearing forces in the circumferential line of column capital as follows:

$$
\left(Q_{\alpha}\right)_{r=R}=\left(\frac{1+\sqrt{2}}{2} a-R\right) w-\left(\frac{\sqrt{2}-1}{2}\right) a w \cos 4 \theta
$$

Let us rewrite the shearing forces in the following form :

$$
Q_{\alpha}=A_{0} \frac{\log \left(\frac{r}{a}\right)}{\log \left(\frac{R}{a}\right)}+A_{4} r^{-4} \cos 4 \theta
$$

where $A_{0}$ and $A_{4}$ are constant. If the coefficients $A_{0}$ and $A_{4}$ are determined form the boundary conditions in $r=R$, the shearing forces lead to

$$
\begin{aligned}
Q_{\alpha}= & \left(\frac{1+\sqrt{2}}{2} a-R\right) w \frac{\log \left(\frac{r}{a}\right)}{\log \left(\frac{R}{a}\right)} \\
& -\frac{(\sqrt{2}-1)}{2} a w\left(\frac{R}{r}\right)^{4} \cos 4 \theta
\end{aligned}
$$

The values of the first team of $\mathrm{Fq}$. (6), which were calculated for the various ratios of $R$ to $a$, are shown in Fig. 9 (a), (b) and (c).

The experiment with membrane has been performed for the purpose of comparison with the results of this calculation,

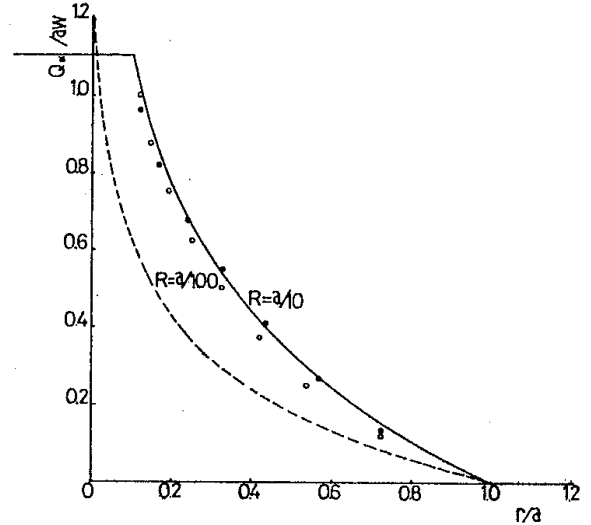

Fig. 9 (a) Shearing forces near and in the column capital in case of $R=a / 10$. 


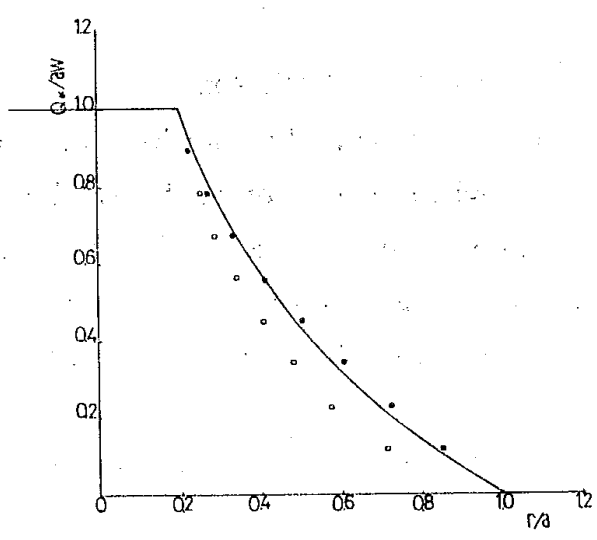

Fig. I (b) Shearing forces near and in the column capital in case of $R=a / 5$.

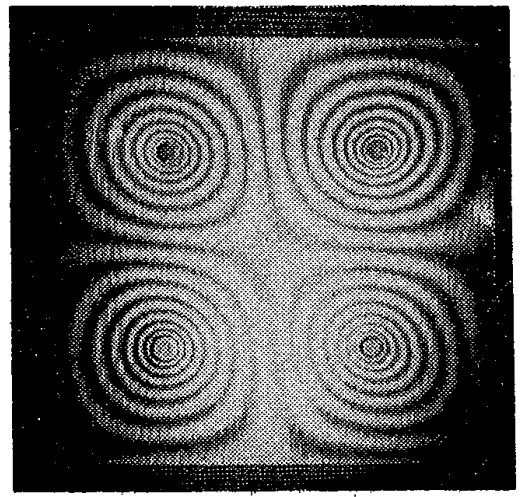

Photo. 3 Contour lines in the flat slab in case of $R=a / 10$.

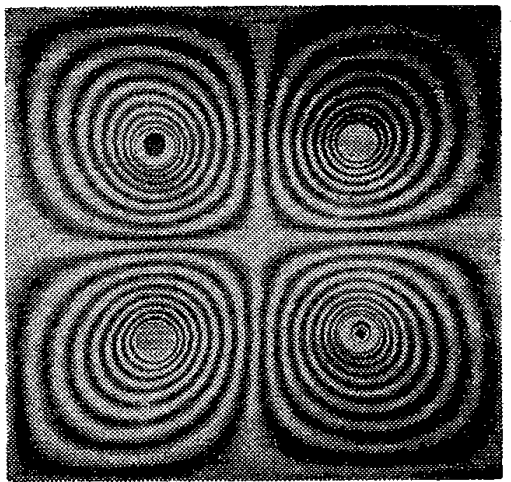

Photo. 4 Contour lines in the flat slab in case of $R=a / 5$.

as shown in Photo. 3, 4 and 5. In Fig. 9, the experimental values in the column row line are expressed by the solid points and these values in the diagonal line by the hollow points. Since the contour lines are assumed to be the concentric circle, the values of shearing forces under this assumption are relatively different at the area far from the column capital, but these values are well agree near and in the column capital. The numerical values of the last term of $\mathrm{Eq}$. (6) are graphically shown in Fig. 10. In order that the variable $r^{4}$ is included in the denominator of the last term of Eq. (6), the values of shearing forces decrease rapidly as the place is far from the edge of column capital, and hence there is little influence for

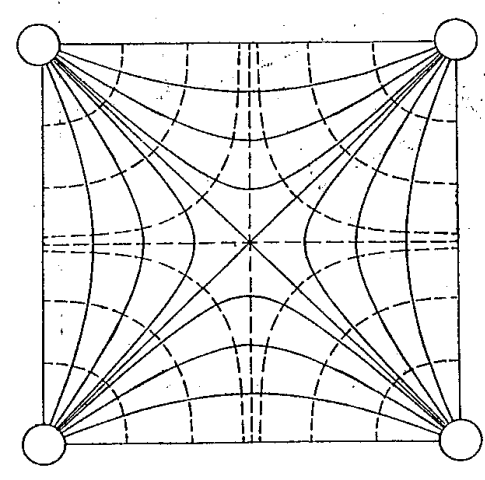

Fig. 11 (a) The primary and secondary beams in the case of $R=a / 10$ when the column capital is large.

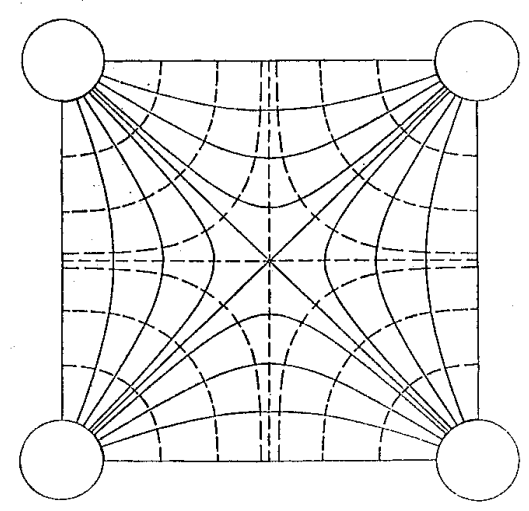

Fig. 11 (b) The primary and secondary beams in the case of $R=a / 5$ when the column capital is large.

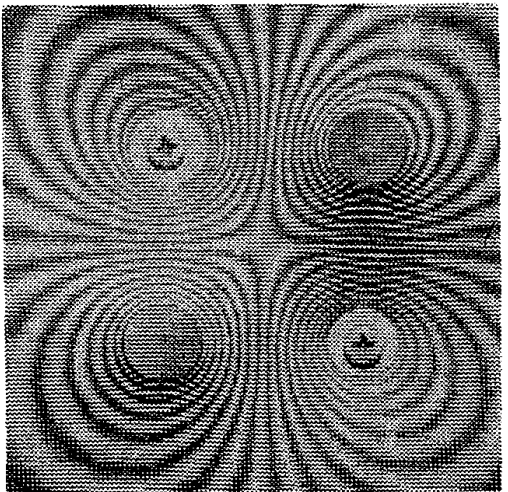

Photo. 5 Contour lines in the flat slab in case of $R=a / 2.5$

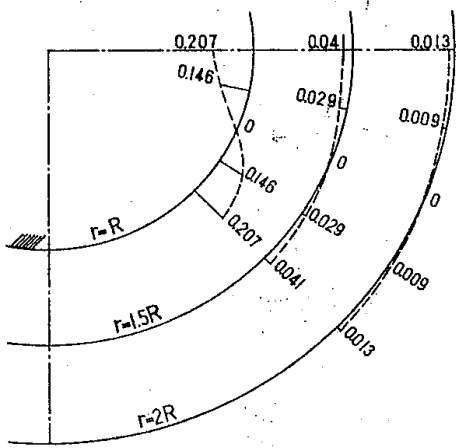

Fig. 10 Influence due to change of shearing forces along the circumferential edge of column capital.

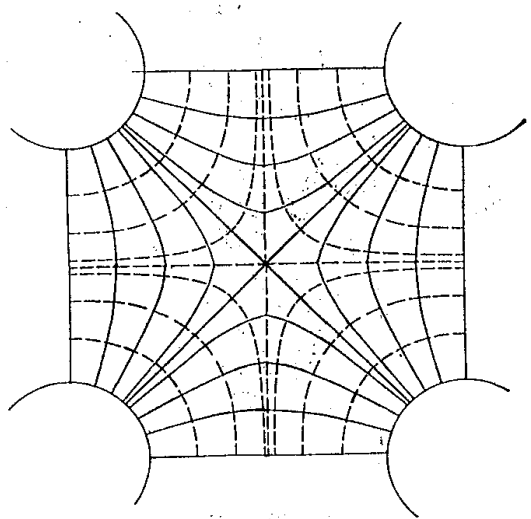

Fig. 11 (c) The primary and secondary beams in the case of $R=a / 2.5$ when the column capital is large. 
the shearing forces in the entire area of the flat slab.

\section{FLAT SLAB STIFFENED WITH ONE-WAY CURVED BEAM SYSTEM}

When the column capital is small, the potential lines of fluid in which the outflow and inflow points exist alternately, show the direction of the secondary beam while the stream lines the direction of the primary beam. Eq. (6) holds the solution near and in the column capital. The value of the second term in this equation decreases rapidly at the place being far away the column capital. Therefore, even if it is assumed that the shearing force $Q_{\alpha}$ is constant along the boundary of the column capital, there is little difference between exact values and those.

Fig. 11 (a), (b) and (c) demonstrate the primary and secondary beams of one-way curved beam system which have been obtained from Photo. 3, 4 and 5 .

\section{ADDITIONAL REMARKS}

The total amount of bending moments in the flat slab supported by the bay of $2 a$ has been compared in both cases where the column row lines are orthogonal and skew. Let us consider the following conditions; $a=7.5 \mathrm{~m}, c=2.96 \mathrm{~m}^{(3)}$ and $w=1 \mathrm{t} / \mathrm{m}$. From the previous monograph the sum of bending moments in the area a $a$ of the flat slab whose column row lines are orthogonal can be found as

$$
Y_{1}=518.3 \mathrm{tm} \cdot \mathrm{m}
$$

While, under the same conditions the sum of them in the flat slab with the skew column row lines can be obtained by

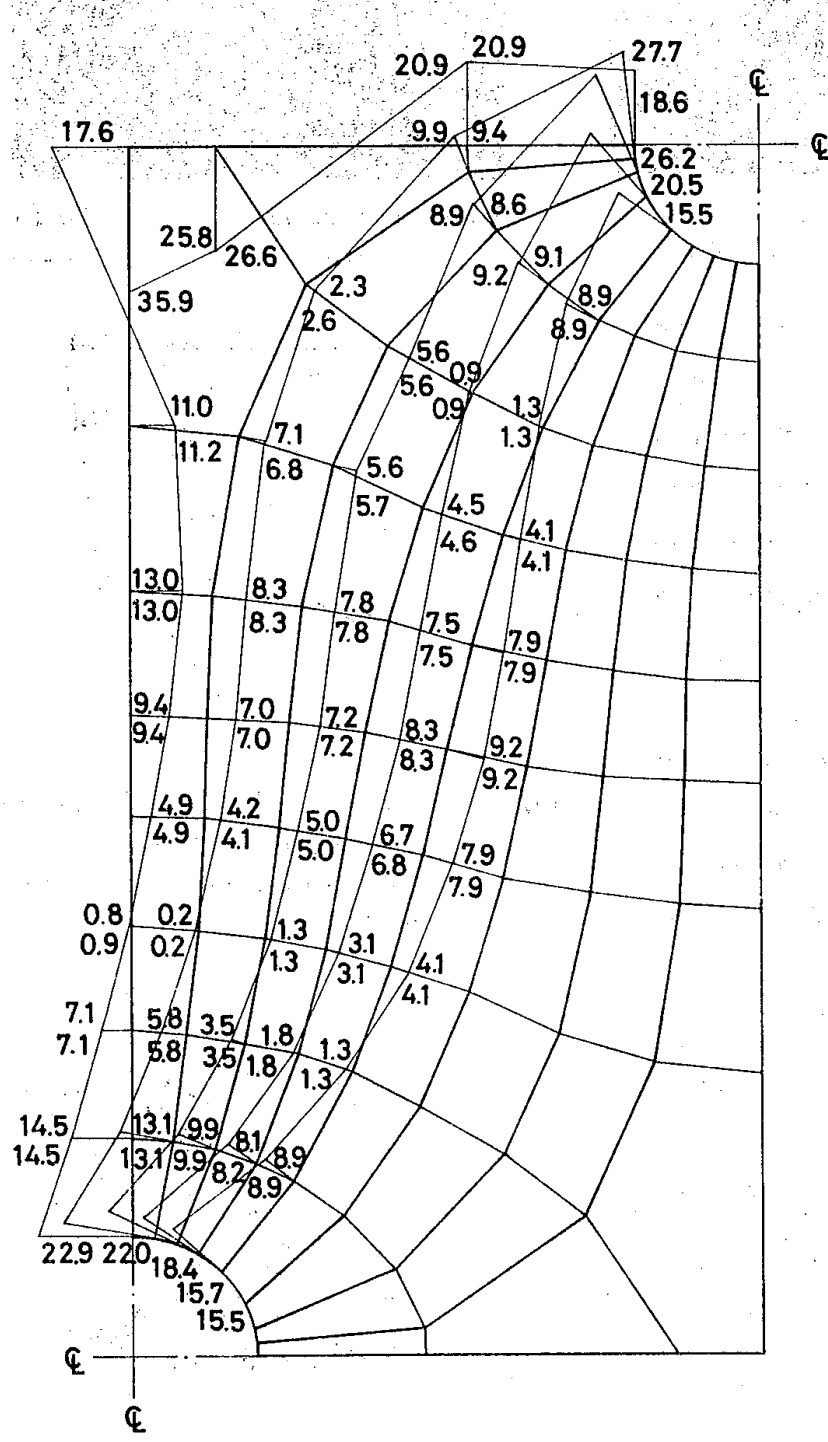

Fig. 12 (a) Bending moments in the primary beam of the flat slab with skew column row line.

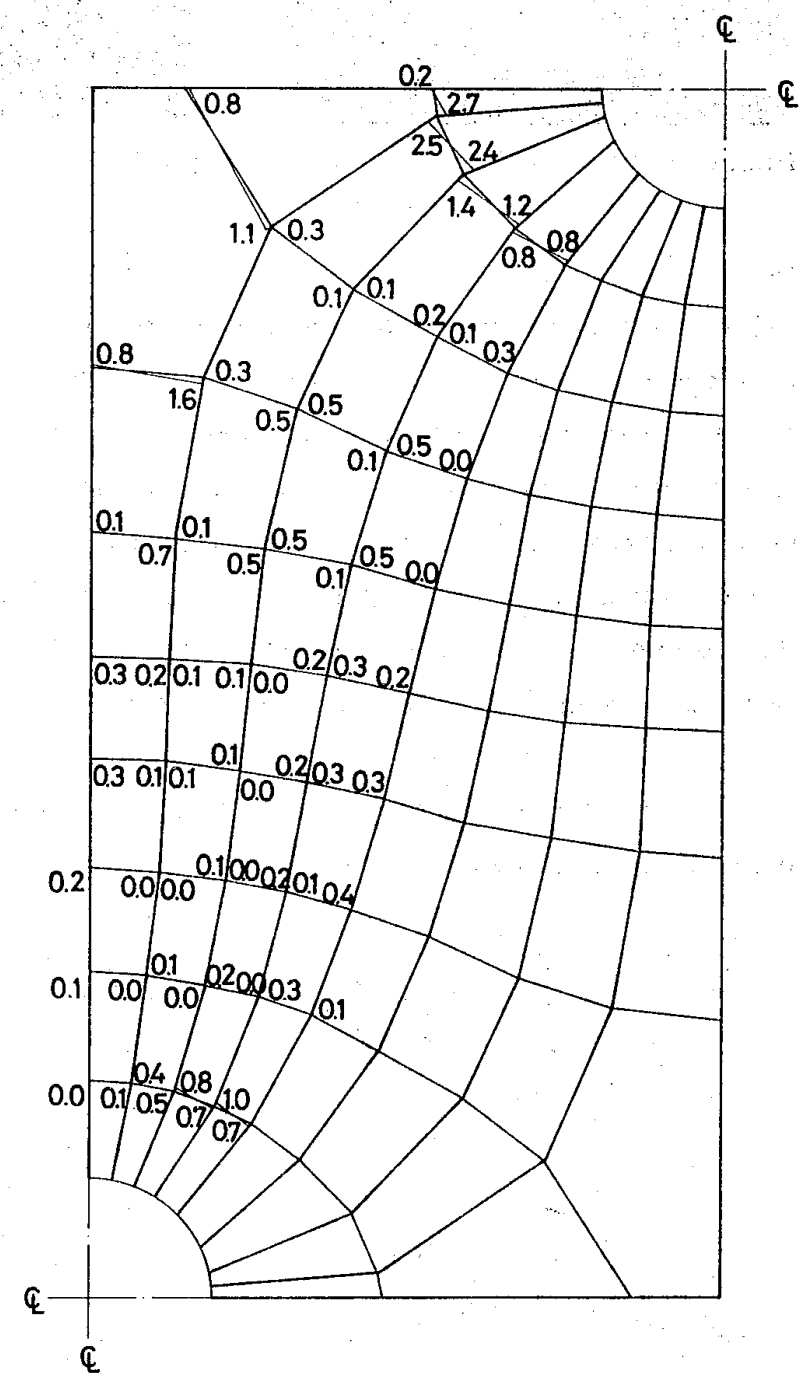

Fig. 12 (b) Bending moments in the secondary beam of the flat slab with skew column row line.

(3) In the previous monograph ${ }^{(1)}$ the constant $c$ is not equal to $2.50 \mathrm{~m}$ but $2.96 \mathrm{~m}$. 


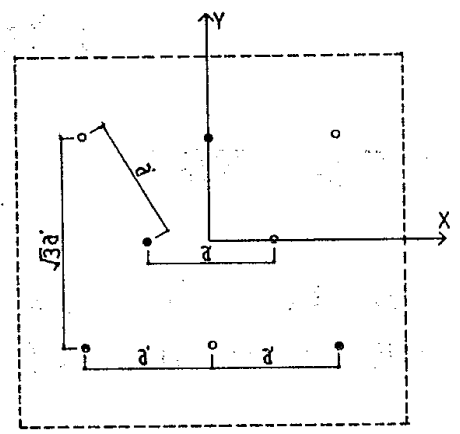

Fig. 13. Field of fluid corresponding to the flat slab in which the column: row lines form the regular triangle.

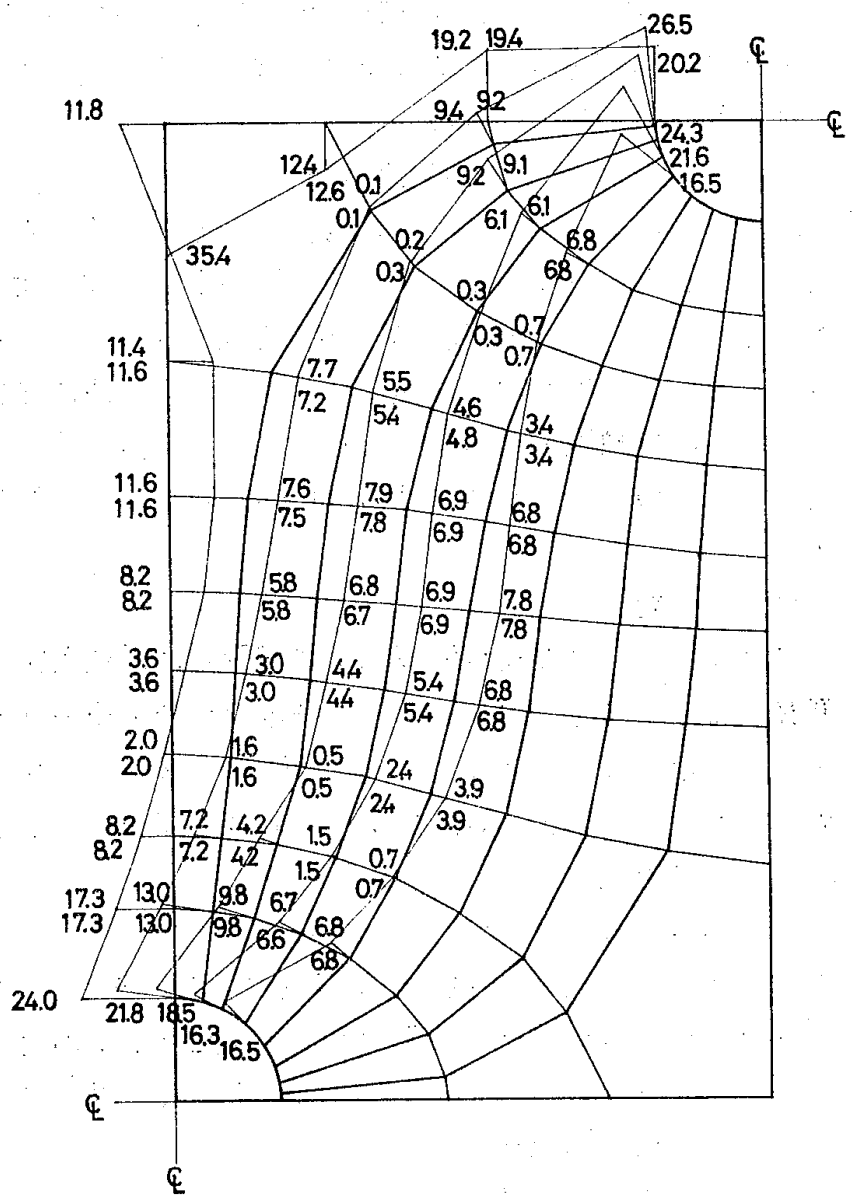

Fig. 15 (a) Bending moments in the primary beam of the flat slab with the column row lines forming the regular triangle.
Fig. 14 A family of primary and secondary beams of the flat slab in which the column row : lines form the regular triangle.

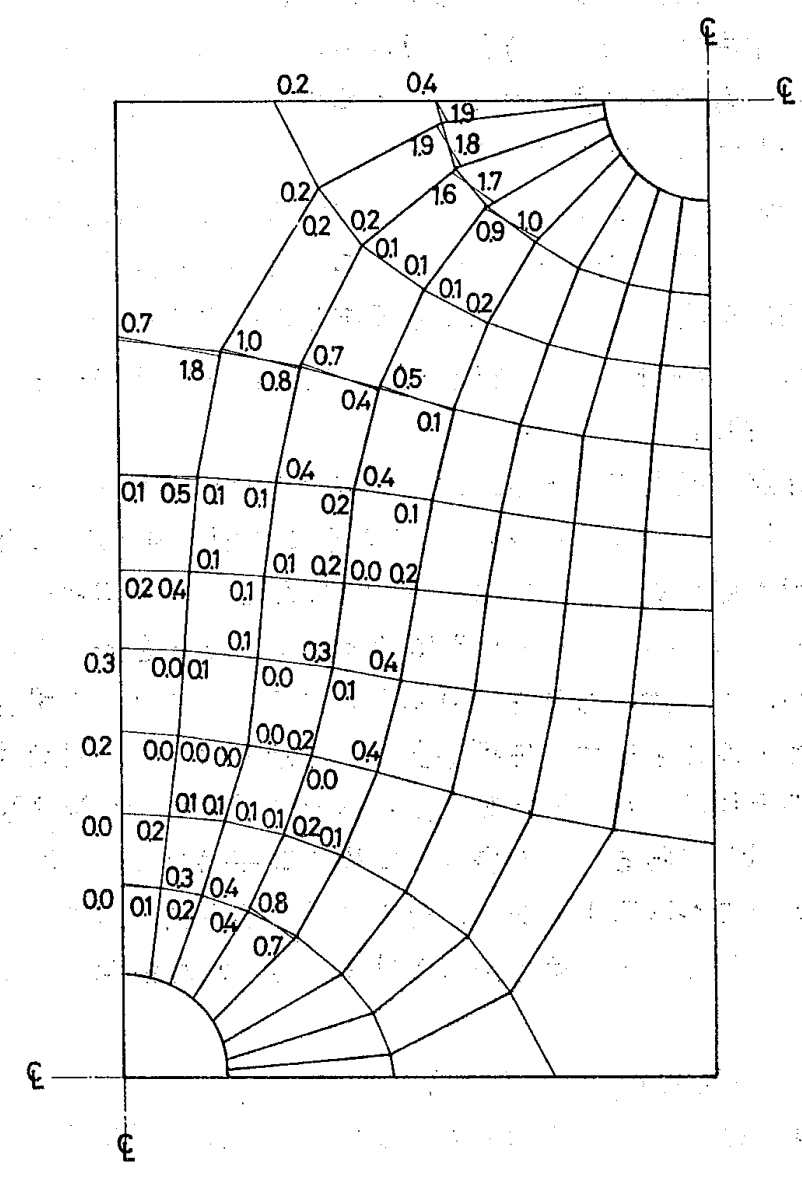

Fig. 15 (b) Bending moments in the secondary beam of the flat slab with the column row lines forming the regular triangle.

$$
Y_{2}=520.3 \mathrm{tm} \cdot \mathrm{m}
$$

The difference between both values is only 0.4 percent.

In Fig. 13 shown are the bending mowents in the flat slab whose columns have the equidistant bay $2 a^{\prime}$ in all directions and where the column row lines form a regular triangle. In this case, it is assumed to be $a^{\prime}=(\sqrt{2} / 4 \sqrt{3}) a$ so that the governing area in a column may be all equal. Fig. 15 (a) and (b) show thebending moments in the primary and secondary beams, in which the sum in the area $a \times \sqrt{2} a^{\prime}$ of this flat slab is given by

$$
Y_{3}=482.9 \mathrm{tm} \cdot \mathrm{m}
$$

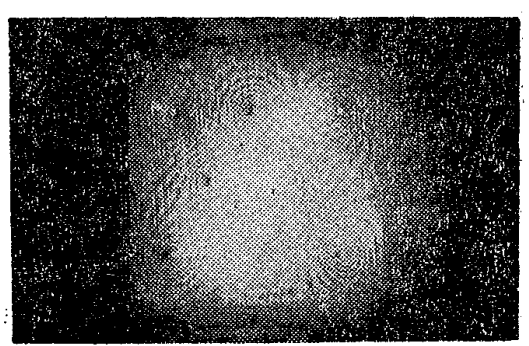

Photo. 6. Contour lines in the flat slab in the cäse whenthe column row lines form the regular triangle.

This value is less 6.8 percent than that of $Y_{1}$. 


\section{一方向曲線梁で補強のフラットスラブ (梗概)}

正会員松 井 源 吾*
正会員十代田

フラットスラブは倉庫や車庫のように荷重の大きい場 合によく用いられるが，柱間隔が大きいときにはリブ (梁)をつけた方が経済的である。ネルビー氏，青木繁教 授による曲線梁江有名であるが，それらはすべて等方性 板の主曲げ方向に曲線梁が設けられている。本論文の曲 線梁は著者の方法, 寸なわち大梁のみが荷重を伝達する ものとすると流体の流線が大梁，ポテンシャル線が小梁 に一致することにより求めた曲線梁である。前論文にて フラットズラブの一例についてのべたが，本論文では一 般的に理論および実験により研究した結果を報告する。

1. フラットスラブと流出点, 流入点のある流体との 相似

原点に流出点のある二次元定常流の複素ポテンシャル は（1）で示される。第 1 図のように 2 個の流出点, 2 個 の流入点があるときは（2）式が求まる。この実数部は (3) 又は (3)' 式となり流体のポテンシャルを表してい るが, $m$ に適当な值を入れると,フラットスラブの場合 のせん断力を表す。柱列線上のせん断力は (4)，対角線 上のそれは (4)' となる。これらを図示したのが第 2 図 (a), (b) である。この場合の薄膜の等高線をモアレ法で 求めたのが写真 1 であり，その結果を第 2 図に黒点でプ ロットしている。第 3 図は実験より得られた曲線梁であ る。

\section{2. 柱列線が斜交する場合}

第 4 図のように柱列をずらした場合，柱列が 2 列であ るとカルマンの渦列に相当し，(5) が得られる。第 5 図, 第 6 図はそう計算值である。写真 2 は膜実験でその結果 を前図に黒点でプロッ小しているが， 2 列と 3 列の差の ため多少違っている。後者による曲線梁を第 7 図に示し ている。

\section{3. 柱頭近傍の検討}

上記では柱頭の径が非常に小さいものとしているが， この点について検討する。柱頭の大きさを考慮した解と して (6) を得る。(6) の第 1 項について $R$ と $a$ との 比を変えて計算した結果を第 9 図 (a)，(b)，(c) に示す。

* 早稲田大学教授 **工学院大学教授 （昭和 52 年 4 月 27 日本稿受理・討論期限昭和 52 年 12 月末日）
これに対応して行った実験が写真 $3,4,5$ である。実験 值の柱列線上の点を黑丸で, 対角線上の点を白丸で第 9 図にプロットしているが，柱頭付近では近似している。 （6）の第 2 項について数值計算したのが第 10 図である。 この項は柱頭周をはなれると急激に減少するので全体に 及ぼす影響はきわめて少ない。

\section{4. フラットスラブの曲線梁補強}

以上要するに, 柱頭の小さい場合には流出点流入点の 交互に存在する流体のポテンシャル線が小梁方向を流線 が大梁方向を示す。柱頭近傍の解として (6) 式が成り 立つ，またその第 2 項は柱頭からはな机ると急激に減少 するので，柱頭境界で $Q_{\alpha}=$ const としても全体的には 変らない。得られた曲線梁は第 11 図 (a); (b)，(c) で ある。

付 記

フラットスラブの柱が間隔 $2 a$ で配置され；柱列線が 直交している場合，斜交している場合の比較を総曲げモ ーメント量によって行なった。 $a=7.5 \mathrm{~m}, c=2.96 \mathrm{~m}$, $w=1 \mathrm{t} / \mathrm{m}^{2}$ とすると，前論文より柱列線が直交するとき は $a \times a$ の範囲で

$$
Y_{1}=518.3 \mathrm{tm} \cdot \mathrm{m}
$$

であった。同じ条件で柱列線が斜交しているときの One-Way Curved Beam System の大梁と小梁の曲げ モーメント図を第 12 図 (a)，(b)に示す。この場合には $Y_{2}=520.3 \mathrm{tm} \cdot \mathrm{m}$

であり，その差は $0.4 \%$ にすぎない。

次に第 13 図のよ5にフラットスラブの柱が全ての方 向に等しい間隔 $2 a^{\prime}$ で並び，柱列線が正三角形を形づ くるときの総曲げモーメント量を求めた。写真 6 にモア レの実験写真を，第 14 図に写真 6 より求められた OneWay Curved Beam System の大梁，小梁群を示す。こ の場合注，柱一本当りの支配面積が同じものとなるよう に $a^{\prime}=(\sqrt{2} / 4 \sqrt{3}) a$ として計算した。第 15 図 (a), (b) に大梁, 小梁の曲げモーメント図を示す。総曲げモ ーメント量は $a^{\prime} \times \sqrt{3} a^{\prime}$ の範囲で

$$
Y_{3}=482.9 \mathrm{tm} \cdot \mathrm{m}
$$

となり，Y尼比へて $6.8 \%$ 少なくなっている。 